Luo, T. (2016). Augmenting combat power: Military translation in China-Burma-India Theater.

Linguistica Antverpiensia, New Series: Themes in Translation Studies, 15, 143-161.

\title{
Augmenting combat power: Military translation in China-Burma- India Theater ${ }^{1}$
}

\section{Tian Luo}

Chongqing Jiaotong University, China

University of Macau, China

kkkluo@foxmail.com

Despite the growing academic interest in translators and interpreters in war situations, there is still a need to discuss the nature and role of translation from the perspective of military principles. This paper, drawing upon the theories about combat power, defines military translation as an intangible factor of combat power involving information and knowledge, and proposes a framework to map out how translation acts upon the internal mechanism of war. Based on the relevant historical records about and memoirs by the interpreters serving in the China-Burma-India Theater, the case study was able to discover that interpreters contributed greatly to the victory of the Alliance through their bilingual services that increased tangible and other intangible factors of combat power, and aided in its execution. This paper concludes that military translation can help reshape the combat power relations between the parties involved in conflicts, and ultimately influence the outcome of the war.

\section{Introduction}

The role of translators and interpreters in war can never be underestimated. In the Pacific Theater in World War II, more than 6,000 Nisei linguists, who were second generation Japanese Americans, served in the US army and worked as translators, interpreters and interrogators (McNaughton, 2006; Takeda, 2007). They contributed to the victory of America to such a degree that General Charles Willoughby, MacArthur's Chief of Staff for Intelligence, remarked that "their work shortened the war by two years" (McNaughton, 2006, p. 460).

Recently, there has been increasing academic interest in military translation (see Apter, 2006; Dragovic-Drouet, 2007; Inghilleri, 2008; Salama-Carr, 2007; Stahuljak, 2000, 2010; Footitt \& Kelly, 2012; Footitt \& Tobia, 2013). Baker (2006, 2010), for example, draws on narrative theory to position translators and interpreters as participants in the construction of war narratives. She investigates how they are narrated by other participants in the war zone, and how they participate in elaborating the range of public narratives of the conflict and, in so doing, influence the course of the war. Rafael (2007) suggests that translation is an instrument 
of surveillance that magnifies the aliennesss of alien speech and a tool of empowerment because it can establish connections and contacts across linguistic and other divides. Wong (2007), adopting a historical-descriptive approach, chronicles the work of translators and interpreters during the Opium War between Britain and China, and foregrounds their multiple roles which were crucial but have been overlooked in the historical record.

As the above-mentioned studies have shown, scholars have agreed on the indispensable role of translators and interpreters in conflict zones and discussed it from narrative, cultural or historical perspective. However, military translation has rarely been approached within the framework of military principles. Further investigation still needs to be done about whether translators and interpreters can act upon the internal mechanism of war, reshape the power relations and influence the result of war. The present paper tries to address the issue of military translation by referring to military theory and by examining the case of interpreters in the ChinaBurma-India Theater (hereafter referred to as "CBI Theater").

\section{Translation, combat power and war}

In this section, some concepts about combat power will be reviewed and a framework to map out the role of military translation in war will be proposed. To avoid redundancy, translation is used in this paper as an umbrella term including both written rendition and oral interpretation that transfer information and knowledge across different languages.

To know what military translation is in nature, it is necessary to understand in advance the concept of combat power. According to Principles of War, combat power, as the direct instrument for war, is often a decisive element in the victory over the opponent (West, 1969, pp. 1213). The USA Army Field Manual 3-0 defines combat power as "the total means of destructive, constructive, and information capabilities that a military unit or formation can apply at a given time" (HDA, 2008, p. 4-1). It is a potential that can be converted into effective action by army command. In a set time and space, the result of battle is determined by the respective combat powers of adversaries, and the side with the greater combat power will win (Raymond, 1993, p. 30).

It is generally agreed that in combat power, there are tangible and intangible factors (HDA, 2011; US Marine Corps, 1997a, 1997b; West, 1969, pp. 11-14). Tangible factors refer to "the number of persons (military personnel strength) and the quantity and quality of material" (West, 1969, pp. 12-13). These measurable factors include the quantity of soldiers, weapons and equipment, logistics and other physical elements. As the basis for combat power, they are used as destructive power, tactical mobility, and other physical strengths.

Intangible factors are understood as "the mental and bodily capabilities of the individuals and groups that comprise the military units 
(forces), the most important one being the spiritual strength of the units and forces" (West, 1969, pp. 11-14). These less easily measured factors include military intelligence, quality of leadership, state of discipline, troop morale and fighting spirit, quality of training, the spirit of teamwork, etc. Two characteristics of intangible factors are manifest: firstly, they are indivisible elements attaching to tangible factors and contributing to victory; and secondly they change greatly, depending on people and conditions.

There is an interaction between tangible and intangible factors. Changes made to either of them will lead to the alteration of the other. If intangible factors are effectively managed, the overall combat power can be multiplied; if poorly managed, the combat power will be reduced.

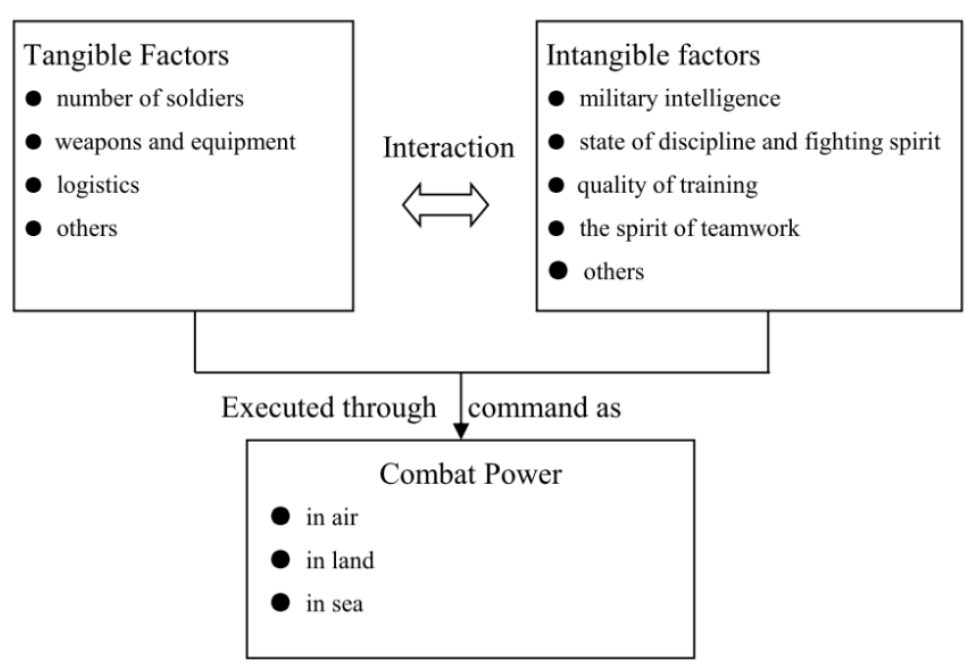

Figure 1. Tangible and intangible factors of combat power

In a given time and space, both tangible and intangible factors are generated or executed into combat power in air, land or sea by command as shown in Figure 1 (based on HDA, 2012a , pp. 5-19; Nedialkov, 2007, p. 55; West, 1969, pp. 11-14). In war, commanders apply the potentials of combat power into operations of fires, movement and manoeuvre, protection and sustainment by using leadership and information. To accomplish mission command, they need to share information, knowledge and perceptions so as to integrate and enhance action. Commanders are put in charge of the following tasks: (1) drive the operations process through their activities of understanding, directing, and assessing operations; (2) develop teams both within their own organizations and with joint or multinational partners; (3) inform and influence audiences inside and outside their organizations. 
Before we discuss how translation influences the combat power as well as the result of war, we need to understand in advance another two key factors in the process of command: information and knowledge. They are two closely related concepts, as important as lethal action in determining the result of military operations.

Information is a "critical, and sometimes the decisive factor in campaigns and major operations" (HDA, 2008, pp. 7-1). Over 2,000 years ago, Sun Tzu has pointed out the importance of information in warfare: "If you know the enemy and know yourself, you need not fear the result of a hundred battles" (Sun Tzu, Giles trans., 1910, p. 24). Intelligence is a type of information about the current or potential adversary, used to understand the enemy and to support force generation. Every engagement, battle, and major campaign requires information. Information is conveyed to various audiences such as adversaries, neutral parties and friendly forces. In war, commanders at all levels depend on information and intelligence particularly "to make informed decisions on how best to apply combat power" (HDA, 2012a, p. 3-1). They also use information and intelligence as a weapon against enemy command and control, and as a tool to boost the friendly morale, so as to increase the effectiveness of the warfighting (HDA, 2008, pp. 4-1-4-3). Information can have a great impact on the tangible factor of combat power. For instance, "disruption of the flow of information or corruption of the information itself can negate the effects of weapons and systems" (HDA, 1996, p. iv). Therefore, in war, every party tries its best to develop the capacity in information collection, processing, and dissemination. Such information operations involve cultural, social, political, and economic issues within the area of military operations and target at sources such as people, equipment, and documents.

Knowledge is the understanding obtained from analysis of information and data, or "the comprehension gained through study, experience, practice, and human interaction that provides the basis for expertise and skilled judgment" (HAD, 2012b, p. 1-2). There are two types of knowledge in the army: tacit and explicit knowledge. Tacit knowledge means each individual's personal store of knowledge gained from life experiences, training, and networks of acquaintances. It is important to the leaders' decision-making and to the subordinates' performance. Explicit knowledge consists of written or documented information that can be organized, applied and transferred, such as dictionaries, field manuals, technical manuals, tactics, and memorandums. It is important to support situational awareness and shared understanding. Two kinds of knowledge operation are common in the army: knowledge transfer and creation (HAD, 2012 b, p. 1-3). Knowledge shall be moved from one person to another, between individuals and units. Knowledge creation means developing new knowledge or combining existent knowledge in response to identified knowledge gaps. Knowledge is created when there is a new technology, or when the commander requires critical information. 
Based on the understanding of the concepts about combat power and its execution, a framework is proposed to investigate the role of translation in war as shown in Figure 2. This framework provides an insight into military translation: what it is in nature, and how it influences the result the war.

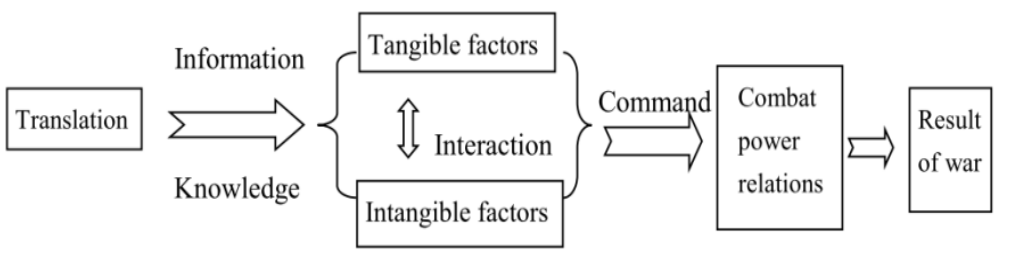

Figure 2. The role of translation in war (based on HDA, 1996, pp. 1-11)

Military translation may occur between friend and foe, or among different parties in a coalition. When a war breaks out between tribes, nations, or international groups speaking different languages, a need emerges for translators or interpreters to provide linguistic service. In other cases, if there is a joint military operation inside a coalition by soldiers from different language communities, a demand for translation also surfaces. Translation may cover the whole duration of war, as pointed out by Baker (2006) that the very process of mobilizing military power and management of conflict is heavily dependent on continuous acts of translation.

Translation, if put within the above-mentioned framework of combat power, falls into the category of intangible factor. Firstly, translation does not function as physical strength such as weapons and equipment contributing directly to the destructive power. Translators and interpreters usually do not act as the soldiers fighting with guns in the battlefield. Secondly, similar to other intangible factors such as intelligence, fighting spirit and quality of training, translation cannot be measured with numbers. However, its contribution to the overall combat power cannot be neglected as it involves information and knowledge that is critical in every war. In this sense, translation constitutes a unique and indispensable intangible factor of combat power.

Military translation works with information and knowledge to increase the tangible and other intangible factors of combat power. Translators' and interpreters' bilingual capacity enables them to spread among the officers and soldiers the valuable military, geographical, social, and cultural information that are essential for successful operations. They can transfer both tacit and explicit knowledge in military training to enhance the soldiers' skills in surveillance, charging, fighting, or retreating. If translators and interpreters help in teaching soldiers how to use a new weapon from other countries, fire power can be amplified. More importantly, translators and interpreters may become creators of the knowledge needed in the battlefield for the improvement of combat power 
by translating technical or tactics manuals. As pointed out by Tymoczko and Gentzler (2002), in polyvalent and multicultural environments, "the act of translation is itself very much involved in the creation of knowledge" ( $p$. xxxiii).

Translation is also important in the command, or the execution of combat power. As we have known, information is crucial for commanders to make and disseminate effective decisions. Translators and interpreters can help ensure the availability, protection, and delivery of information. In most cases, intelligence about adversary party is gathered through translation. When describing, assessing and leading operations among troops featured international partnership, commanders may need assistance from translators and interpreters for the sake of communication and teamwork. If commanders want to inform and influence audiences outside their organizations speaking different languages, translators and interpreters are also needed.

To sum up, military translation can be viewed as an intangible factor of combat power involving information and knowledge. It may exert a great impact on other factors of combat power as well as its execution, change the relative combat power relations between/among the parties involved in war, and consequently become influential or even decisive to the outcome of a war.

In the following part, the results of a case study of interpreters in the CBI Theater will be reported, using the analytical framework proposed above. The interpreters' role in war will be discussed from the three aspects, namely tangible factors, intangible factors and the execution of combat power, after an overview of the CBI Theater is given.

\section{The CBI Theater and its need for interpreters}

CBI Theater is a term used by the United States Army for the battle zones of China, Burma, and India, where the Allied air and land forces fought against the Japanese army. In 1941, the Japanese forces occupied Burma and cut off the China-Burma Road, the last supply line between China and the outside world. In order to help China to reach international aid, the CBI Theater was established in 1942 by the Alliance. In April 1945, the Alliance won a great victory, with the Japanese troops being driven out of Burma and southwest China, and the China-Indian Road, another overland supply route, being reopened for China. The victory in the CBI Theater ensured the safety of southwest China, supported the American counteroffensive in the Pacific Theater and constituted a great contribution to the global war against Fascism.

Various causes for the victory of allied armies in the CBI Theater, such as good quality of training, advanced weaponry and air supremacy, have been addressed by scholars (e.g., Liu, 2008; Ni, 2007). However, the research on the role of interpreters in winning this war is scarce. The 
present paper takes translation in the CBI Theater as a case for study for the following reasons: firstly, the recruitment and service of interpreters lasted over five years from 1941 to 1945 ; secondly; more than 4,000 interpreters were involved in the war, a rare number in war history; and thirdly, translation was done not only for the conflicts between friend and foe, but also for cooperation among the Allied troops. Therefore, the CBI Theater becomes a typical locale to investigate military translation.

The great, urgent demand for interpreters came mainly from the communication among the parties involved in the CBI Theater (see Figure 3). On the Alliance side, there were Chinese, US and British forces; while on the Japanese side, there were the Japanese army and some surrendered Burmese soldiers. In the Alliance, Chinese troops were the largest in quantity, seconded by US forces, with the British soldiers being a small proportion. Consisting of mainly Chinese Expedition Forces and the Chinese Army in India, the Chinese troops added up to 400,000. According to the statistics, in April 1945, the US forces in the China Theater alone amounted to 43,100, including more than 31,300 in the air force, 11,100 in ground forces, and 700 in other units (Romanus \& Sunderland, 1959, p. 258). Famous US units included the Flying Tigers, the 5307th Composite Unit (Provisional), and the 5332nd Brigade (Provisional).
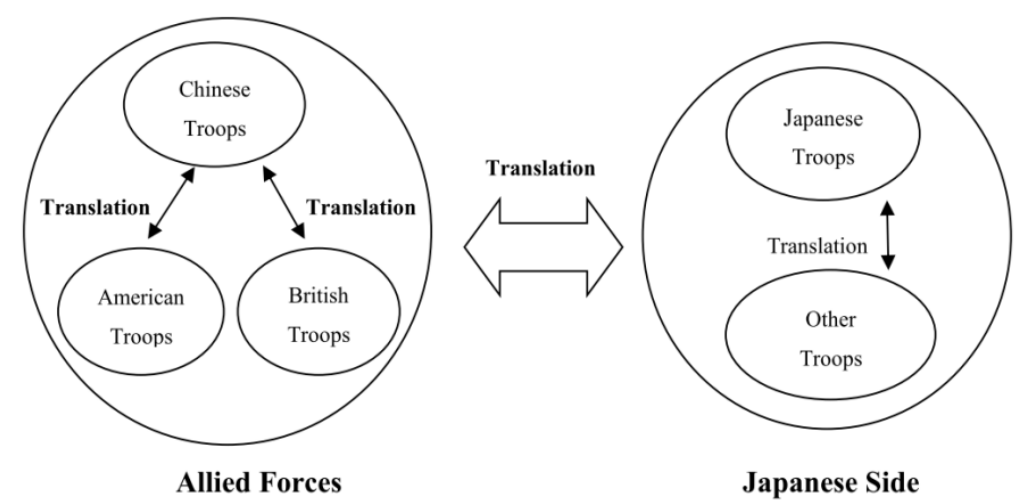

Figure 3. Translation among the parties involved in the CBI Theatre

In order to ensure smooth communication between the Chinese troops and US army men coming in increasing numbers since 1941, US liaison officers and advisors were assigned to each battalion, regiment and division (Wang, B., 2005, pp. 183-186). However, a huge linguistic gap existed between Chinese forces and US counterparts. At that time, most of the Chinese officers could hardly understand English, and few of the US officers spoke Chinese. As a result, a large number of US soldiers were stuck in the hotel and the military facilities from US were stored up in the warehouse without being timely dispatched to battlefields (Tang, 2005, pp. 174-178). Due to time and financial constraints, it was impossible and 
impractical to train all the relevant officers or soldiers with bilingual competence. Eventually, the only solution was to recruit interpreters from within China, to provide them with a short training and to send them out to perform linguistic service.

The recruitment of interpreters began as early as August 1941, when the American Volunteer Group (AVG), a team of fighter plane pilots, came to China's aid to provide air defence and to operate the "over-the-hump" flights. As they needed interpreters in handling the military and logistic affairs, the War Area Service Corps of the Chinese Nationalist Government began to recruit military interpreters.

Later, when the demand for interpreters in the CBI Theater increased drastically, the Chinese Foreign Affairs Bureau (FAB) took the responsibility of enlisting more interpreters and running interpreter schools to offer training in both language and military affairs. Altogether, over 4,000 interpreters were recruited from within China, most of them were college students who knew both Chinese and English (Luo, 2011). They were given a brief training of several weeks, and dispatched to various locations in India, Burma and China for bilingual service in the army. Their presence can be found in US units such as the Flying Tigers and the 5307th Composite Unit, Chinese Expedition Forces and the Chinese Army in India, the Chinese Aviation Committee, various kinds of training centers or schools, and logistics departments. Their service period ranged from one year to three years. When the war in the CBI Theater ended in April 1945, most of the interpreters left the army.

These Chinese linguists in the CBI Theater in most cases dealt with oral interpretation between English and Chinese, and they were usually called "interpreters" in American documents and 译员 in Chinese files. However, it has to be noted that they also engaged in written translation from time to time. Since these interpreters were employed and paid according to their corresponding military ranks as captains, majors or lieutenant colonels, they were also addressed as 翻译官 in Chinese, or as "interpreting officers" in English and occasionally "fan-i-kuan" according to the Chinese pronunciation of 翻译官. The present paper follows suit and refers to these linguists as interpreters, without any intention to exclude their work in written translation.

The focus of our study is on the Chinese interpreters working for Chinese and US troops due to two reasons. Firstly, this paper discusses how interpreters contribute positively to the result of the war and the Alliance was the victorious side. Secondly, there are much more relevant data at hand about the interpreters in the Allied Forces than that about the interpreters in the Japanese side.

To ensure that our study is representative of the 4,000 interpreters in the CBI Theater, relevant data were gathered from a variety of sources by different authors from different countries from 1945 to 2012. They include 70 memoirs by interpreters who themselves served in the CBI Theatre (e.g., Chen, 2003; Mei, 2004; Wang, 2003; Xu, 1996; You, 1945), 
18 pieces of oral history scripts (e.g., He, 2004), 8 texts of news reports about the CBI Theater by the US and Chinese Army during World War II (e.g., Sultan's HQ, 1945), 10 journal papers (e.g., Jiang, 2007a, 2007b; Ni, 2007), 3 academic monographs on military history (e.g., Romanus \& Sunderland, 1959), $2 \mathrm{PhD}$ theses on the US-China military (e.g., Pickler, 1971) and other unpublished file records. The large number of first-hand accounts by interpreters themselves constitutes a valuable source from which we can gain an overall and detailed understanding of their work in the war. Other texts serve as supporting evidence from different perspectives.

The purpose of this descriptive and interpretive case study is to arrive at a deep understanding of translation in the CBI Theater with detailed analysis and to test the applicability of the framework to investigate the role of translation in war as proposed above. Relevant data are analysed from three aspects: tangible factors, intangible factors and the execution of combat power. Examples of interpreters are enlisted from the data source to showcase how interpreters contribute to these three aspects. For each individual interpreter, attention is given to who he was, where and when he performed his tasks, and more importantly how his translation contributed to the increase of combat power. Generalization is then made on the basis of the analysis of individual examples. The findings of the analysis are presented in the following sections.

\section{Interpreting for tangible combat power}

Weaponry and equipment is one of the key tangible factors of combat power. In the CBI Theater, interpreters participated in the process of receiving, distributing and utilising weapons and equipment, and contributed to the increase of tangible combat power of the Allied Forces.

In the CBI Theater, the combat power of the Chinese troops increased to a large extent when the majority of them were facilitated with advanced US-made weapons, ammunition, vehicles, telecommunication and medical equipment. For instance, each division of The New First Army of The Chinese Expedition Forces was equipped with 3,000 vehicles, 200 cannons, 300 scatter-guns, 300 sub-machineguns or carbines in addition to flamethrowers and bazookas. Besides, soldiers were provided with the American-style field gears which included their uniform, helmet, boots, backpack, rifle, and bayonet.

Interpreters aided in the supply and the distribution of weaponry. When the 50th Division of the Chinese Army in India were fighting in the jungles of northern Burma, the supplies were mostly air-dropped. Items needed by the Chinese army were listed through interpreters and then turned over to the American liaison group, who would inform the rear services via radio for airdrop in batches. Wang Ruifu, like many other interpreters, helped in the supply of weapons (Wang, R., 2005, pp. 187- 
198). You Xin once worked in the US Liaison Group which was in charge of food, weapons and ammunition supply (You, 1945, p. 47).

Interpreters also translated the manuals, instructions and specifications of weapons so that they could be properly and extensively used by the Chinese army. This process involved not only information transmission, but also knowledge transfer or creation. For instance, in December 1943, Mei Zuyan worked as an interpreter in the US Army headquarters in Kunming, to ensure the cooperation between the relevant American and Chinese ordinance departments which were in charge of the production of Americanised weapons in Kunming, such as rifles and machineguns. When the US Army was putting the flamethrower in trial operation, a weapon able to inflict violent and lethal burns with great destructive power, Mei Zuyan translated the manual, which was crucial for its subsequent extensive use (Mei, 2004, p. 55). In this example, Mei Zuyan aided in the increase of tangible power through the creation and transfer of tacit knowledge about weapon usage in the Chinese army.

Some interpreters promoted the technological advancement in the army with their linguistic service. For instance, about 15 college students majoring in engineering were purposefully recruited by the Chinese General Sun Liren so that they could work as both linguists and experts for technique improvement in the army. Some of them majoring in civil engineering were sent to the engineering or artillery battalion. Some in mechanics served in vehicles battalion or the ordinance department in division headquarters. Others, like Jiang Dazong and Yun Zheng, were dispatched to telecommunication units and put in charge of the maintenance and replenishment of the telecommunication apparatus (Jiang, 2007a, p. 68). Wang Bohui, a student from the Civil Engineering Department of the National Southwest Associated University, worked as one of many interpreters in engineering battalions which undertook construction tasks in the army. In January 1945, when two American engineering companies were building a 440-foot-long "Bailey bridge" for quick manoeuvring of troops across a river, Wang Bohui and another interpreter assisted Captain Carey, the supervisor of the construction project. They participated in the decision-making and helped in speeding up the construction (Wang, 2005, p. 186).

Interpreters were also important in the proper function of the American medical apparatus supplied to the Chinese army. Since the healing of the wounded may mean more soldiers fighting in the front line, medical treatment can contribute to the increase of tangible combat power. For instance, In the 20th General Hospital in the CBI Theater, an interpretation department was set up to ensure the medical treatment for wounded soldiers, since the hospital was run by American army doctors while most of the patients were Chinese soldiers (Jiang, 2007b, p.74). Zhang Xiuzheng, after being trained for two weeks about medical terms, worked as an interpreter in a field hospital in north Burma (Zhang, 2013). According to $\mathrm{Yu}$ (1997, pp. 102-103), who worked with the 73th 
Evacuation Hospital, there were twenty wards for patients and fourteen interpreters. Each morning, doctors, nurses and interpreters would survey the wards in a team. Interpreters worked with nurses' reports, doctors' inspection and consultation, and patients' questions. LaVonne Camp (1997, p. 39), one of the American nurses who worked at the 14th Evacuation Hospital in the CBI Theater, remembered that when she was assigned to a ward filled with about fifty Chinese patients, the Chinese Army provided her with an interpreter, "a real necessity". Her interpreter, Yang Jei-pen, was a serious young man, well educated and very helpful in keeping the names of the patients sorted out.

The role of interpreters in weaponry and equipment was acclaimed by Roundup, a free weekly newspaper printed in India, published by and for the US Forces in the CBI Theater. It was composed of news and pictures supplied by staff members, war correspondents, and War Department news services. On April 12, 1945, there was a feature by Sultan's Headquarters in Burma, entitled Chinese Fan-I-Kuan Mouthpieces for American Liaison Officers, reporting the role interpreters played in the military conflicts. It highlighted interpreters' contribution to the proper function of weapons and equipment:

They are indispensable at rear echelon ordnance automotive maintenance depots where Chinese soldiers are being taught American know-how in operation and maintenance of jeeps, trucks, and command cars. Without them, American-commanded, Chinesemanned artillery couldn't function. (Sultan's HQ, 1945, p.7)

The news article also commented favourably on the role of interpreters in medical assistance: "They are a vital cog in their operation of American portable surgical hospitals attached to Chinese combat troops" (Sultan's HQ, 1945, p.7).

\section{Interpreting for intangible combat power}

In the CBI Theater, a large number of interpreters assisted in the military training, intelligence gathering and transmitting, as well as liaison and teamwork. All these contributed to the boost of intangible factors of combat power.

With regards to military training, combat power becomes decisive when applied by skilled commanders leading well-trained soldiers and units (HDA, 2008, p. 4-2). In the CBI Theater, one of the missions for US troops was to train the Chinese army with military tactics and knowledge in using US weaponry and equipment. For this purpose, the infantry School, the Field Artillery School, the Drivers School, the Command and General Staff School, as well as many other training centres were established in Kunming, Chongqing, Guilin and other locations (Romanus and 
Sunderland, 1959, p.20). For instance, in August 1942, General Joseph Stilwell began to train the Chinese Troops in India at the Ramgarh Training Center and over 32,000 soldiers were trained under the supervision of American officers according to the American standards (Feng, 2000, pp. 206-215).

A large number of interpreters offered their linguistic aid in military training. A typical example is related to Cao Yuehua. In the beginning of 1943, he and other 19 college students were recruited as interpreters by the FAB and worked in the artillery, infantry, and drivers school under the direction of the Kunming Cadre Training Center of the Chinese National Military Council (Cao, 2004, pp. 53-56). Cao Yuehua was assigned to the artillery school, where the American army took charge of the management and teaching affairs. There were four training groups: the cannon, telecommunication, animal packing, as well as veterinarian group. Cao Yuehua worked in the vet group, interpreting for more than 10 American teachers. After having interpreted for several sessions, he could give additional help by supplementing what the teachers neglected. In April 1945, the number of interpreters working in the Kunming Field Artillery Training Center alone reached 160 (Wong, 1995). Lu Guowei was an interpreter who worked for the US Combat Staff. In May to July, 1944, his major task was to translate weapon manuals and textbooks for field operation training. He finished translating piles of such documents in less than a month. He then volunteered and went to interpret in the Tank School at the Ramgarh Training Center in India (Lu, 2005, pp. 50-55).

"The interpreters were indispensable" at the Ramgarh Training Center (Romanus \& Sunderland, 1953, p. 119). American officers served as the primary instructors and trainers, supported by hundreds of Chinese student interpreters (Babb, 2012, p. 130). According to Huang (2005, p. 90), who was a soldier in the 5th Company, 2nd Battalion, Technical Training Regiment in the Chinese Army in India being trained at Ramgarh, each company had "one American lieutenant-commander coach officer, one Chinese lieutenant-commander interpreter and four American sergeants". Interpreters "paired off with American instructors to teach the Chinese soldiers everything from how to fix flat tires to how to load a mule with pack artillery" (Weidenburner, 2005).

As Pickler (1971, p. 259) commented, interpreters were also "absolutely essential" in the training of Chinese air force pilots and technicians. From 1943 to August, 1945, the American Air Force offered a variety of courses for about three thousand Chinese at thirteen different training sites in America (He, 2004, p. 252; Pickler, 1971, p. 261). Each training site employed at least six interpreters. Consequently, sixty interpreters were serving in early 1945 and yet twenty-one were needed (Pickler, 1971, p. 261).

Next, we will discuss military intelligence. Intelligence supports the commander across operations and "helps the commander decide when and where to concentrate sufficient combat power to overwhelm the enemy" 
(HDA, 2010). Interpreters also played an indispensable role in the collecting, processing and circulation of intelligence in the CBI Theater.

Wang Ruifu, for example, translated and reported intelligence about enemy presence, military maps as well as air photos (Wang, R., 2005, p. 193). The main task of Cheng Yaode, an interpreter in Transition and Editing Office of the Chinese Aviation Committee, was to translate the intelligence about enemy activity sent from staff office every day and deliver it to the US Army Combat Command in China (He, 2004, pp. 249251). He translated information about the re-deployment of the Japanese forces along the Peking-Hankou Railway, the location of Japanese airports, barracks, and warehouses, as well as the transportation on the Yangtze River. His work was a great aid in the bombing against Japanese troops by Allied airplanes from rear bases. Lin Guangmin, an interpreter in the 14th Air Force, once translated a piece of intelligence saying a ten-thousandton Japanese ship carrying ammunition had reached the harbour of Hankou in preparation for unloading. This translated intelligence was very helpful. The next day, a news report confirmed that the Japanese ship had been sunk by Allied bombing with all the ammunition on the ship destroyed (He, 2004, pp. 253-254).

Now, we will discuss liaison and teamwork. Liaison is the contact or intercommunication maintained between elements of military forces or other agencies to ensure mutual understanding and unity of purpose and action. "Liaison activities augment the commander's ability to synchronize and focus combat power" (HDA, 2011, pp. 9-1). Interpreters, by bridging the linguistic gap, contributed to the better liaison and teamwork among different units of the Alliance in the CBI Theater.

The liaison and cooperation among troops from different countries in the Alliance called for interpreters' aid. The victory at the battle of Bhamo, Namhkam and many other places greatly depended on the collaboration among the allied forces. For instance, in the Battle of Myitkyina in May, 1944, there was a close cooperation between Chinese combat forces (such as the 42nd and 150th Chinese Infantry Regiments) and the US 5307th Composite Unit (Provisional). In these battles, the linguistic support from the interpreters was indispensable in liaison.

Inside some US-Chinese joint units, interpreters were also needed for smooth communication. For example, in the Joint Chinese-American 1st Provisional Tank Group activated at Ramgarh, India in 1943, there were over 200 American soldiers and officers in the 1st and 2nd Battalions, and more than 1800 Chinese soldiers in the 3rd through 6th Battalions. For such joint units, interpreters were essential to connect the English speaking officers with Chinese counterparts. Other units, like The 5332d Brigade (Provisional), known as the Mars Task Force, consisting of the 475th Infantry, 124th Cavalry and 1st Chinese Regiment, also had a great demand for linguistic aid.

Lack of interpreters from time to time would result in the reduction of combat power. Major W. Loar Gerguson, a liaison officer with a Chinese 
tank group, believed that whenever there was a mishap or a slip-up in an operation, it had been due to the absence of a fan-i-kuan who could make things clear to officers and men (Sultan's HQ, 1945). Lt. Col. McPherson LeMoyne, who was attached to a tank unit, stated that without interpreters, American troops would "be groping in the fog" (Sultan's HQ, 1945, p. 7).

Fortunately, interpreters, on most occasions, managed to establish sound communication between the Chinese and American troops, boosted up the teamwork, and finally contributed to the increase of combat power in the CBI Theater. Lt. Col. Wellus A. Rhodes commented on the interpreters:

They live with us and learn to interpret our thoughts with complete fidelity. Most of them know the importance of their mission, understand the importance of good feeling, unanimity and cooperation among Chinese and Americans. Each one feels it is part of his job to increase this spirit of co-operation. Most of them will do anything to make things better. (Sultan's HQ, 1945, p.7)

\section{Interpreting for the gain of air supremacy}

In the CB Theater, interpreters aided in the execution of combat power, for instance, in the gain of air supremacy. Air supremacy is a position where one side holds complete control of air warfare and air power over adversary forces. Before 1941, the Chinese air force was rather weak, and the surrender of air to Japanese planes led to the severe losses on the Chinese side. However, the situation changed when Flying Tigers began to provide assistance. Flying Tigers is a term for the three blood-related US air forces fighting for China, AVG set up in August 1941, US Army 23rd Fighter Group established in July 1942, and 14th Air Force (hereinafter referred to as 14th AF) established in March 1943. They maintained the same insignia and used similar tactics under the command of Claire Lee Chennault. From the beginning of 1944, the Flying Tigers, together with the Chinese air force, won the air supremacy in southwest China. By the end of World War II, China claimed air superiority over all parts of its sky. The Flying Tigers made a remarkable contribution to the Allied victory in the CBI Theater with regards to air attacks and defence, cargo transport, and coordinated operations in the battles (Wei, 2005, pp. 88-92).

Since air fighting features rapidity and flexibility, there is higher demand for timely intelligence and prompt battle commands to win in the air. Interpreters can come to aid in gathering and transmitting intelligence of the enemy air force and issuing out battle commands. Aware of the importance of linguistic support, translation and edition departments were established in both US and Chinese air units to the make use of the bilingual competence and subject knowledge of interpreters. Many examples have displayed the vital role of interpreters in aiding the Flying Tigers to 
compete against Japanese air forces, such as Li Chengde (Chen, 2003), Xu Yuanchong (Xu, 1996, pp. 113-123), and Wang Shizhong (Wang, 2003).

One typical instance is Li Chengde, who worked as an interpreter for Chennault. One of his tasks was to translate the intelligence needed by the American air force (Chen, 2003, pp. 7-11). On December 20, 1941, he received a piece of intelligence in Chinese saying 10 Japanese planes were going to attack Kunming. After a quick translation into English, this message was delivered to Chennault. Because of the timely reporting of this intelligence, Chennault had enough time to plan for the coming fighting. The next day, well prepared AVG pilots beat the Japanese airplanes when they flew near Kunming. As a result, 6 Japanese planes were knocked down and 3 heavily damaged, without any loss on the AVG side. At the celebration that night, AVG soldiers and officers were hailed as heroes. Li Chengde was also highly appreciated for his translation and Chennault went up to toast him for his significant support (Chen, 2003, p. 9). In this example, the prompt translation of intelligence became the prerequisite of a quick and smart decision in commanding.

At the beginning of 1944, the 14th Air Force planned to take charge of the air defence in north China. Six air-ground liaison teams were organized and sent out to get the timely first-hand intelligence from headquarters at different battle areas so as to send planes to air-bomb enemy in cooperation with the ground forces (Wang, 2003). Each team consisted of an American intelligence officer, two telegraphers, and an interpreter. Wang Shizhong and Yan Binyuan worked respectively in two of these air-ground liaison teams as interpreters, contributing to the air supremacy in north China. They gathered intelligence about the location of Japanese barracks, warehouses, arsenals, ships and airports, the manoeuvring of Japanese forces, and the transportation on Yangtse River as well as along railways in north China. Much valuable intelligence was obtained, collated and sent back to 14th Air Force, which were helpful in bombing attack of allied air force (He, 2004, p. 247-251).

To ensure the proper operation of the air force, a translation and editing department was established in the 5th Command of the Chinese air force. The major task of the Department was to translate the intelligence upon receipt and exchange with the headquarters of 14th $\mathrm{AF}(\mathrm{He}, 2004$, pp. 253-254). In 1944, there were four interpreters with the Department: one working for the Commander, while Lin Guangmin and another two were translating the daily intelligence, the official documents as well as the daily battlefield report from 14th AF. The information and intelligence was about the situations of both sides in war and other issues such as the request for the 14th AF to coordinate in battles. At 19:00 each day, intelligence was sent by phone or radio from the 1st Section of the Aviation Commission in Chongqing to the 1st Department of the 5th Command. Three interpreters took turns to work at night. Sometimes, there was such a large amount of information received that they had to work till the next morning. This example once again illustrates that interpreters' work was 
important for the smooth communication and efficient command of the US and Chinese air forces in the CBI Theater.

\section{Conclusion}

In the CBI Theater, interpreters were active in various Allied units. They could "be found with the Chinese Infantry, with the Mars Task Force, with American-Chinese tank units" (Sultan's HQ, 1945, p.7). Our case study discovered that interpreters helped transmit the needed information among different units of the Alliance, and were involved in the transfer and creation of knowledge. The influence of these interpreters on the war can be summarized in three ways: they aided in the enhancement of tangible factors of combat power, such as weapons and equipment; boosted other intangible factors, such as military training, intelligence, liaison and teamwork; and contributed to the efficient execution of combat power, such as the gain of air supremacy. All these added up to the effect that translation increased the combat power, and eventually contributed to the victory of the Allied Forces.

The case study revealed that translation, as an intangible factor of combat power, can impact on the internal mechanism of war and play a crucial role for victory. It will continue to do so because future warfare is increasingly dependent on information superiority and knowledge advantage.

\section{References}

Apter, E.. (2006). The translation zone. Princeton, NJ: Princeton University Press.

Babb, J. (2012). The harmony of Yin and Yank: The American military advisory effort in China, 1941-1951 (Ph.D thesis, University of Kansas).

Baker, M. (2006). Introduction. In Mona Baker (Ed.). Translation and conflict: A narrative account. London: Routledge.

Baker, M. (2010). Interpreters and translators in the war zone: Narrators and narrated. The Translator, 16(2), 197-222.

Camp, L. (1997). Lingering fever: A World War II nurse's memoir. Jefferson, NC: McFarland.

Cao,Y. (2004). Experiencing CBI Theatre. Gems of Culture and History, (8), 53-56. [曹 越华. (2004). 中印缅战场亲历记. 文史精华, (8), 53-56. ]

Chen, W. (2003). Adventures of Li Chengde, an interpreter for Claire Lee Chennault. Chronicle of Literature and History,(5), 7-11. [陈文欣. (2003). 黎成德:“飞虎 队”陈纳德将军贴身翻译传奇经历.文史春秋, (5), 7-11. ]

Dragovic-Drouet, M. (2007). The practice of translation and interpreting during the conflicts in the Former Yugoslavia (1991-1999). In M. Salama-Carr (Ed.), Translating and interpreting in conflict (pp. 29-40). Amsterdam: Rodopi. 
Feng, J. (2000). General Joseph Stilwell. Beijing: Peace Press. [冯嘉琳. (2000).史迪 威将军北京: 中国和平出版社. ]

Footitt, H., \& Kelly, M. (2012). Languages at war: Policies and practices of language contacts in conflict. Basingstoke: Palgrave Macmillan.

Footitt, H., \& Tobia, S. (2013). War talk: Foreign languages and the British war effort in Europe, 1940-47. Basingstoke: Palgrave Macmillan.

Giles, L. (Trans.). (1910). The Art of War: The oldest military treatise in the world. London: Luzac \& Co.

He, Y. (2004). The fighting by 800 students from National Southwest Associate University: Interpreters from the graduates of 1944. In Institute of Modern History of Chinese Academy of Social Sciences (Eds.). Sources in modern Chinese history, 109 (pp.212-259). Beijing: Chinese Social Science Press. [何 宇. (2004). 西南联合大学八百学子从军记-1944 届从军学生的译员生涯. 社会科学院近代史研究所《近代史资料》编辑部编. 近代史资料,109 (pp.212-259). 北京: 中国社会科学出版社]

Headquarters of the Department of Army (HDA). (1996). Field manual No. 100-6 information operations. Washington, DC: Author.

Headquarters of the Department of Army (HDA). (2008). Field manual No. 3-0 operation. Washington, DC: Author.

Headquarters of the Department of Army (HDA). (2010). Field manual No. 2-0 intelligence. Washington, DC: Author.

Headquarters of the Department of Army (HDA). (2011). ATTP. 5-0.1 Commander and staff officer guide. Washington, DC: Author.

Headquarters of the Department of Army (HDA). (2012a). ADRP 3-0 unified land operations. Washington, DC: Author.

Headquarters of the Department of Army (HDA). (2012b). Field manual No.6-01.1 knowledge management operations. Washington, DC: Author.

Huang, S. (2005). Days in Ramgarh. In X. Deng (Ed.). Under same army flag: Recollections of the National Chinese Army veterans of World War II (pp.9092). Beijing: China Intercontinental Press. [黄书泽. (2005). 在兰姆伽的日子. 邓贤主编. 在同一面战旗下(pp.90-92). 北京: 五洲传播出版社.]

Inghilleri, M. (2008). The ethical task of the translator in the geo-political arena: From Iraq to Guantánamo Bay. Translation Studies, 1 (2) , 212-223.

Jiang, D.(2007a). Memories in the Anti-Japanese War. Medical and Health Care Instruments, (4), 69-72. [蒋大宗. (2007a). 抗日从军回忆. 医疗保健器具, (4), 69-72. ]

Jiang, D.(2007b). Memories in the anti-Japanese War. Medical and Health Care Instruments, (6), 74-79. [蒋大宗. (2007b). 抗日从军回忆. 医疗保健器具, (6), 74-79. ]

Liu, Y. (2008). What led to the victory of Chinese Expedition Forces and Chinese Troops in India in the North Burma and West Yunnan Campaign. Journal of Chengdu University (Social Science), (2), 41-43. [刘咏涛. (2008). 中国驻印军、 远征军反攻缅北滇西胜利的原因. 成都大学学报(社会科学版), (2), 41-43. ]

Lu, G. (2005). Memories of interpreters among the Chinese Troops in India. Beijing observation, (9), 50-55. [卢国维. (2005). 驻印抗日远征军译员生活回忆. 北 京观察, (9), 50-55.] 
Luo, T. (2011). Interpreting officers at the Burma Campaign during the Second World War. In L. W. Wong (Ed.) Studies in translation history(pp.223-249). Shanghai: Fudan University Press. [罗天. (2011). 滇缅战役中的军事翻译.翻译史研究 (pp. 223-249). 上海: 复旦大学出版社.]

McNaughton, J. C. (2006). Nisei linguists: Japanese Americans in the military intelligence service during World War II. Washington, DC: Department of the Army.

Mei, Z. (2004). Essays in old age. Beijing: Tsinghua University Press. [梅祖彦. (2004). 晚年随笔. 北京: 清华大学出版社. ]

Nedialkov, D. (2007). Examining air power as a component of state power. Information \& Security, An International Journal (Transforming Air Forces), 21(1),53-68.

Ni, L. (2007). The victory of Chinese Expedition Forces revisited and its impact on the World War II. Military Historical Research, (2), 48-65. [倪乐雄. (2007). 再论 中国远征军成败及对第二次世界大战战局的影响一兼从制空权的角度分 析缅甸战局. 军事历史研究, (2), 48-65.]

Pickler, G. K. (1971).United States aid to the Chinese Nationalist Air Force, 1931-1949 (Ph.D thesis, The Florida State University).

Rafael, V.(2007). Translation in wartime. Public Culture, 19(2), 239-46.

Raymond, A. D. (1993). Assessing combat power: A methodology for tactical battle staffs. Kansas: School of Advanced Military Studies, US Army Command and General Staff College.

Romanus, C. \& Sunderland, R. (1953). Stilwell's mission to China. Washington, DC: Office of the Chief of Military History, Department of the Army.

Romanus, C. \& Sunderland, R. (1959). Time runs out in CBI. Washington, DC: Office of the Chief of Military History, Department of the Army.

Salama-Carr, M. (Ed.). (2007). Translating and interpreting conflict. Amsterdam: Rodopi.

Stahuljak, Z. (2000). Violent distortions: Bearing witness to the task of wartime translators. TTR, 1,37-51.

Stahuljak, Z. (2010). War, translation, transnationalism: Interpreters in and out of the war (Croatia 1991-1992). In M. Baker (Ed.). Critical readings in translation studies (pp.391-414). London: Routledge.

Sultan's HQ. (1945, April 12). Chinese Fan-i-kuan mouthpieces for American liaison officers. Roundup, p.7. Retrieved October 10, 2015 from http://www.cbitheater.com/roundup/roundup041245.html.

Takeda, K. (2007). Nisei linguists during WWII and the occupation of Japan, The ATA Chronicle, 1,14-17.

Tang, Y. (2005). Translation: “A bridge for the Allied troops”. In X. Deng (Ed.). Under same army flag: Recollections of the National Chinese Army veterans of World War II (pp.174-178). Beijing: China Intercontinental Press. [汤毅强. (2005). 翻译: 盟军桥梁. 邓贤主编. 在同一面战旗下: 中国二战老兵回忆录 (pp.174-178). 北京: 五洲传播出版社. ]

Tymoczko, M. \& Gentzler, E. (Eds.). (2002). Translation and power. Amherst: University of Massachusetts Press.

US Marine Corps. (1997a). MCDP1 Warfighting. Washington, DC: Department of the Navy. 
US Marine Corps. (1997b). MCDP 1-3 Tactics. Washington, DC: Department of the Navy.

Wang, B. (2005). At engineer battalion in Indian-Burma Battlefield. In X. Deng (Ed.). Under same army flag: Recollections of the National Chinese Army veterans of World War II (pp.183-186). Beijing: China Intercontinental Press. [王伯惠. (2005). 在印缅工兵营. 邓贤主编. 在同一面战旗下(pp.183-186). 北京: 五洲 传播出版社. ]

Wang, R. (2005). After the Hump Flight: The report by a military interpreter. In X. Deng (Ed.). Under same army flag: Recollections of the National Chinese Army veterans of World War II (pp.187-198). Beijing: China Intercontinental Press. [王瑞福. (2005). 飞越“驼峰”之后一一个随军译员的报告. 邓贤主编. 在同 一面战旗下(pp.187-198). 北京: 五洲传播出版社. ]

Wang, S. (2003). American liaison groups in the Campaigns of Henan, Hu'nan and Guangxi. In Grade 1944 (Eds.). Memoir of 800 students in battle field: Grade 1944 of National Southwestern Associated University (pp.160-162). Beijing: Grade 1944 National Southwestern Associated University. [王式中. (2003). 河 南、湘桂战线上的美军陆空联络组. 西南联大 1944 级. 国立西南联合大学 八百学子从军回忆(pp.160-162). 北京: 西南联大 1944 级.]

Wei, Y. (2005). American Flying Tigers who held the Japanese army in awe: At the $60^{\text {th }}$ anniversary of China's victory in the anti-Japanese War. National Defense Technology, (10), 88-92. [魏岳江. (2005). 威震日寇的美国空军“飞虎队”一纪念抗日战争胜利 60 周年. 国防科技, (10), 88-92. ]

Weidenburner, C. (2005, June 10). Ramgargh Training Center. Retrieved from Rmgargh Training Center website: http://www.cbi-theater.com/ramgarh/ ramgarh.html.

West, J. (1969). Principles of War (A translation from the Japanese). Kansas: Combat Studies Institute, US Army Command and General Staff College.

Wong, L. W. (2007). Translators and interpreters during the Opium War between Britain and China (1839-1842). In M. Salama-Carr(Ed).Translating and interpreting conflict (pp.56-57). Amsterdam \& New York: Rodopi.

Wong, X. (1995). Unforgettable life as a military interpreter. Committee of cultural and historical data, Beijing Committee of CPPCC. Beijing cultural and historical data. 52 (pp.1-47). Beijing: Beijing Press.[翁心钧. (1995). 难忘的军事译员生 活. 北京市政协文史资料委员会编. 北京文史资料. 52 (pp.1-47). 北京：北 京出版社. ]

Xu, Y. (1996). Remembrance of things past. Beijing: SDX Joint Publishing Company. [许渊冲. (1996). 追忆逝水年华. 北京: 生活・读书・新知 三联书店. ]

You, X. (1945). Interpreter's life. High school students. 86, 46-48. [又新. (1945). 译员 生活. 中学生. 86, 46-48.

$\mathrm{Yu}$, C. (1997). Working at the field hospital in Northern Burma jungles. Committee of cultural and historical data, Beijing Committee of CPPCC. Beijing cultural and historical data 10 (pp.96-110). [余成锠.(1997). 在缅北原始森林的战地医院 里.中国人民政治协商会议北京市海淀区委员会文史资料委员会. 海淀文 史选编 10. (pp.96-110).]

Zhang, X.(2013, April 7). Remembrance of being an interpreter in the Burmese battlefield. Retrieved October 10, 2015 from The Huangpu Military Academy 
website. http://www.hoplite.cn/Templates/qnjwsg0008.html. [张修正. (2013 年 4 月 7 日). 缅甸前线做译员杂忆. 2015 年 10 月 10 日登录.黄埔军校网. http://www.hoplite.cn/Templates/qnjwsg0008.html.

1 This work has been supported by the research project 16YJA740025 hosted by Tian Luo and funded by the Ministry of Education of P. R. China. It is also aided by the research programme MYRG2015-00234-FAH hosted by Professor Meifang Zhang at the University of Macau. 